\title{
УДК 340.15
}

DOI https://doi.org/10.32847//n.2021.14.015

Бахтіяров Узейір Маїл огли, аспірант

Науково-дослідного інституту публічного права

\section{ОРГАНІЗАЦІЙНО-ПРАВОВІ ОСНОВИ ДІЯЛЬНОСТІ ПОЛІЦЇ̈ (НА МАТЕРІАЛАХ УКРӒ̈НСЬКИХ ГУБЕРНІЙ У СКЛАДІ РОСІЙСЬКОЇ ІМПЕРІї)}

Постановка проблеми. Беззаперечним, постає той факт, що за всіх часів однією з найважливіших функцій держави була боротьба 3 злочинністю. Відтак, в контексті української державності протягом тривалої історії накопичено багатий досвід, який склав організаційно-правову базу, що регламентує процес попередження, припинення та розкриття злочинів, а також системи органів діяльність яких була зосереджена в окреслених напрямках, а отже, вивчення теоретико-прикладних аспектів становить реальну наукову цінність. Скасування кріпосного права та впроваджуванні реформи на українських землях у XIX столітті, сприяли прискоренню соціально-економічного розвитку. Цей процес супроводжувався розпадом традиційних зв'язків та відносин у суспільстві, насамперед у селі, поглибленням соціального розшарування, збільшенням міграційних потоків, люмпенізацією частини населення, що ставало основою зростання злочинності. Основною силою держави у боротьбі із загально-кримінальною злочинністю в цей період була поліція, яка уособлювала якісно-новий механізм кримінального судочинства, що надалі неодноразово коригувався і вдосконалювався. На цьому фоні особливу значущість набуває необхідність звернення до досвіду створення органів поліції, нормативно-правового та кадрового забезпечення боротьби поліції зі злочинністю, оперативно-розшукової та дізнавальної діяльності, оскільки саме такі аспекти є й сьогодні особливо значущими, крізь призму реформування правоохоронної діяльності та судової системи.
Стан дослідження. В сучасних умовах проблематика пов' язана із дослідженням організаційно-правових засад діяльності поліції посідає чільне місце серед наукових досліджень провідних вчених таких як: О. М. Бандурка, В. М. Білик, I. В. Бондаренко, I. А. Григоренко, А. М. Куліш, А. М. Кучук, О. С. Проневич, І. В. Солов'євич, М. І. Хавронюк, О. В. Шмоткін, Н. С. Юзікова, В. В. Россіхін, А. С. Шевченко, О. Н. Ярмиш тощо.

Але в умовах становлення вітчизняної науки, простежується, що наукові розробки вчених та законодавчі ініціативи, як правило, направлені на вирішення окремих проблем у визначенні функціональних обов'язків органів поліції, їх посадових та службових осіб, а також розширення їх правових засад та здійснюються переважно крізь призму кримінального та адміністративного права. Таким чином, наукові розробки присвячені комплексному дослідженню даній проблематиці потребують подальших напрацювань.

Внаслідок чого, метою даної статі є дослідження та комплексний аналіз організаційно-правових основ діяльності поліції на матеріалах українських губерній у складі Російської імперії.

Виклад основного матеріалу. Однією 3 найважливіших завдань держави $€$ забезпечення внутрішньої безпеки, охорона громадського порядку і боротьба зі злочинністю. Історія державності проходить певні етапи, на кожному з яких стан, організація, місце в державному механізмі органів, які виконують поліцейські функції, мають свої особливості. 
У XIX - початку XX ст. Російська імперія була абсолютною монархією, а отже, визначальною ознакою іiі була необмежена влада. В Основних законах Російської імперії було сказано, що влада з управління державою повністю належала государю [1].

3 появою державності функцію охорони громадського порядку, забезпечення внутрішньої безпеки виконували численні посадові особи, в основному місцевого рівня управління: намісники князів, посадники, тіуни, мечники, пристави, а також вотчинники i поміщики, їх слуги. Розвиток системи управління в XV-XVII ст. став наслідком наділення поліцейськими функціями нових органів центрального управління. Таким чином, в XVII ст. центральна влада починає зосереджувати поліцейську діяльність в своїх руках, але поки компетенція поліцейських органів обмежується в основному межами столиці [2, с. 15].

В процесі державних реформ Петра I завершилася централізація державної влади, утвердилася абсолютистська (самодержавна) форма правління, був реформований весь державний механізм і особливо його карально-правоохоронна частина. Утворені нові органи політичного розшуку. Преображенський наказ і Таємна канцелярія, сформована система фіскалітету, яка була покликана викорінювати зловживання по службі, для здійснення розслідування були направлені на місця гвардійські офіцери 3 надзвичайними повноваженнями, створена прокуратура, зроблена спроба відокремити судову владу і зміцнити iii. Широкі правоохоронні повноваження були покладені на всі органи управління, особливо місцеві (воєвод, губернаторів і їх канцелярії, оберкомендантів, комендантів, різні контори, ратуші і магістрати). На перебудову адміністративно-поліцейського управління вплинула прихильність Петра I до західноєвропейських зразків. Сприймалися не тільки зміст і форма, а й термінологія. Петро I, подовгу бував за кордоном і цікавився там державним управлінням, не міг не ознайомитися 3 організацією і діяльністю зарубіжної поліції, а ряд проектів по перетворенню державного апарату містив обов'язковий розділ «поліція» [3, c. 209].

В першу чергу, створення перших установ регулярної поліції при Петрові I відбувалося в містах $з$ великою чисельністю населення. Початок цьому процесу було покладено в Санкт-Петербурзі. Зведення нової столиці супроводжувалося жорстким примусом населення до забудови, благоустрою та іiі заселення. Детальне регулювання будівництва, скупчення великих мас трудового, переважно чоловічого населення, викликали гостру необхідність удосконалення управління взагалі і поліцейського особливо.

Як і багато інших перетворення Петра I, поліцейська реформа проводилася без чіткого плану і грунтовної підготовки. Разом 3 тим не залишає сумнівів, що загальний задум на створення регулярної поліції на той час уже дозрів. У загальних рисах було намічено формування адміністративно-поліцейського апарату в містах. Чітко простежується певна логічна послідовність у становленні органів поліції: спочатку законодавчо визначалося посадове становище керівника нового закладу, окреслювалося коло його повноважень, потім - на керівну посаду призначалася конкретна особа, яка комплектувала апарат, після чого про орган управління робилося публічне повідомлення [4, с. 88].

Формування апарату регулярної поліції стикалося не тільки з небажанням або неможливістю переїжджати на постійне місце проживання в незручний в той час для проживання Петербург, крім цього позначалася гостра нестача кваліфікованих чиновників. Громадянська служба мало заохочувалася урядом, поліція до того ж не була популярною в народі. Головною особливістю організації поліцейської служби, і не тільки в період іiі становлення, було залучення до неї не тільки обивателів, а й армійських чинів. Саме поліцейським функціям військових в повітах приділяють особливу увагу «Плакат» $\mathrm{i}$ «Інструкція полковнику» [5, с. 200]. 
Поліцейські обов'язки покладалися не тільки на земських комісарів, а й на всіх, кого уряд вважав придатними для виконання поліцейських завдань. Ще раніше, до установи земської поліції 20 червня 1718 року уряд поклав на сільських старост, соцьких, поміщиків деякі поліцейські обов'язки, погрожуючи штрафом за їх невиконання. Після того, як була заснована земська поліція в 1719 р, тим же особам було наказано подавати щотижневі, а в разі віддаленості - щомісячні доповіді про те, чи немає в їх селі злодіїв, розбійників і гулящих людей [6, с. 4].

У законодавчих актах початку XVIII в. вказувалися основні напрямки діяльності поліції, конкретизувалися окремі повноваження, регулювалися форми і методи її функціонування, проте не були визначені в належній мірі межі повноважень, підстави й гарантії, що забезпечують законність поліцейської діяльності. Діяльність поліцейських установ була зумовлена особливостями феодально-кріпосницької економіки, станової організації суспільства, самодержавного ладу держави i його політичного режиму, а також конкретною ситуацією, що складається в столицях, регіонах імперії, суб'єктивними поглядами і бажаннями влади і їі оточення, на прикладі деяких традиційно-властивих їй напрямків діяльності.

Поліцейська реформа Петра I залишилася не завершеною. Регулярна поліція, як i багато інші частини державного механізму Російської імперії, переживали початковий етап розвитку. Але вже в цей час, виявилися специфічні завдання і функції поліції абсолютистської держави, такі принципи організації поліцейської служби, як публічно-правова природа, професіоналізм, нормативно-правова основа, бюрократизм і ін. Органи загальної поліції були відокремлені від органів політичного розшуку, були частиною загально-адміністративного апарату. Вони не брали активної участі в державних перетвореннях, але їх створення і наступні зміни мали глибоке історичне значення [7, с. 40].
Процес формування органів поліції вийшов за рамки столиць лише у другій чверті XVIII століття, коли у багатьох містах, в тому числі українських земель були поліцмейстерські контори для забезпечення правопорядку. До середини XVIII ст. регулярна поліція представляла собою централізований апарат, але не охоплювала поки всю країну. Загальна регулярна поліція залишалася осторонь від палацових переворотів, оскільки народні маси не брали в них участі, але відчувала на собі зміни у вищому керівництві країною, i чим менш стабільним було становище монарха, тим більше уваги він приділяв поліцейським органам, вбачаючи в них опору особистої влади. Однак, про створення професійної поліції в Російській імперії в середині XVIII ст. говорити передчасно. Спеціальної підготовки поліцейських кадрів поки не було створено, а чіткі вимоги до посад поліцейської служби тільки починають визначатися, наприклад важливу роль при призначенні на посаду відігравала висока моральність претендента, його порядність та чесність [8, с. 12].

Таким чином, в першій половині XVIII ст. служба в органах поліції на українських землях у складі Російської імперії переживала початковий період становлення. Держава здійснювала організаційну побудову органів поліції, формувала їх структуру, забезпечувала кадровий склад доступними засобами. Однак в цей час була відсутня продумана програма подальшого розвитку системи поліцейських органів та поліцейської служби. Багато функцій органів поліції на місцях, як і раніше виконували громадські інститути (сільські та міські громади, церковні громади), приватні особи (поміщики, власники заводів) та армія.

Висновки. Таким чином, розкриваючи організаційно-правові основи діяльності поліції постає очевидним, що протягом більш ніж півстоліття, починаючи 360 -х років робилися спроби проведення реформи поліції, суть яких полягала в спеціалізації діяльності поліцейських органів. На цьому шляху була виконана певна робота: в результаті реформування 
юстиції з поліції виділяється судова діяльність, міська і земська реформи вилучили з ії ведення суспільно-господарські функції, інститут земських начальників значно скоротив і спростив іiі обов'язки по відношенню до селянського населення. Змінюється і структура поліції, зокрема, намічаються тенденції до усунення станового аспекту в іiї побудові, держава вживає заходів до посилення свого впливу, централізації полі- цейської структури. Уряд піклується про підвищення авторитету поліцейської служби, вводячи для цього різного роду матеріальні і моральні заохочення. Відбувається остаточне розділення поліцейської та військової сфер діяльності: військові чини (в тому числі і козачі формування), які раніше традиційно залучаються для виконання поліцейських завдань, перестають використовуватися в цих цілях.

\section{Анотація}

Наукова стаття присвячена дослідженню та комплексному аналізу організаційно-правових основ діяльності поліції на матеріалах українських губерній у складі Російської імперії.

3 урахуванням доктринального дослідження аргументовано показано, що за всіх часів однією $з$ найважливіших функцій держави була боротьба з злочинністю. Відтак, в контексті української державності протягом тривалої історії накопичено багатий досвід, який склав організаційно-правову базу, що регламентує процес попередження, припинення та розкриття злочинів, а також системи органів діяльність яких була зосереджена в окреслених напрямках, а отже, вивчення теоретико-прикладних аспектів становить реальну наукову цінність. Скасування кріпосного права та впроваджуванні реформи на українських землях у XIX столітті, сприяли прискоренню соціально-економічного розвитку. Цей процес супроводжувався розпадом традиційних зв'язків та відносин у суспільстві, насамперед у селі, поглибленням соціального розшарування, збільшенням міграційних потоків, люмпенізацією частини населення, що ставало основою зростання злочинності. Основною силою держави у боротьбі із загально-кримінальною злочинністю в цей період була поліція, яка уособлювала якісно-новий механізм кримінального судочинства, що надалі неодноразово коригувався і вдосконалювався. На цьому фоні особливу значущість набуває необхідність звернення до досвіду створення органів поліції, нормативно-правового та кадрового забезпечення боротьби поліції зі злочинністю, оперативно-розшукової та дізнавальної діяльності, оскільки саме такі аспекти є й сьогодні особливо значущими, крізь призму реформування правоохоронної діяльності та судової системи.

Розкриваючи організаційно-правові основи діяльності поліції постає очевидним, що протягом більш ніж півстоліття, починаючи з 60 -х років робилися спроби проведення реформи поліції, суть яких полягала в спеціалізації діяльності поліцейських органів. На цьому шляху була виконана певна робота: в результаті реформування юстиції з поліції виділяється судова діяльність, міська і земська реформи вилучили з її ведення суспільно-господарські функції, інститут земських начальників значно скоротив і спростив іiї обов'язки по відношенню до селянського населення. Змінюється і структура поліції, зокрема, намічаються тенденції до усунення станового аспекту в іiі побудові, держава вживає заходів до посилення свого впливу, централізації поліцейської структури.

Ключові слова: засади діяльності поліції, поліція, органи поліції, українські території у складі Російської імперії, правоохоронні органи, українські губернії, державне управління.

\section{Bakhtiiarov Uzeiir Mail ohly. Organizational and legal bases of police activity (on the materials of Ukrainian provinces as a part of the Russian Empire) \\ Summary}

The scientific article is devoted to the research and complex analysis of the organizational and legal bases of police activity on the materials of the Ukrainian provinces as a part of the Russian Empire. 
Taking into account the doctrinal research, it has been argued that at all times one of the most important functions of the state has been the fight against crime. Thus, in the context of Ukrainian statehood over the long history has accumulated a wealth of experience, which formed the organizational and legal framework governing the process of prevention, cessation and detection of crimes, as well as the system of bodies whose activities were concentrated in the outlined areas. is of real scientific value. The abolition of serfdom and the introduction of reform in the Ukrainian lands in the XIX century, contributed to the acceleration of socio-economic development. This process was accompanied by the disintegration of traditional ties and relations in society, especially in rural areas, deepening social stratification, increasing migration flows, lumpenization of the population, which became the basis for the growth of crime. The main force of the state in the fight against general crime in this period was the police, which embodied a qualitatively new mechanism of criminal justice, which was repeatedly corrected and improved. Against this background, the need to turn to the experience of establishing police bodies, legal and personnel support of the police in the fight against crime, operational and investigative activities is especially important, because such aspects are especially important today, through the prism of law enforcement and judicial reform.

Revealing the organizational and legal basis of police activity, it is obvious that for more than half a century, since the 1960 s, attempts have been made to carry out police reform, the essence of which was to specialize the activities of police bodies. Some work has been done in this way: as a result of the reform of the judiciary, the judiciary stands out from the police, city and zemstvo reforms have removed socio-economic functions, and the institution of zemstvo chiefs has significantly reduced and simplified its responsibilities to the peasant population. The structure of the police is also changing, in particular, there are tendencies to eliminate the class aspect in its construction, the state is taking measures to strengthen its influence, the centralization of the police structure.

Key words: principles of police activity, police, police bodies, Ukrainian territories as a part of the Russian Empire, law enforcement bodies, Ukrainian provinces, public administration.

\section{Список використаних джерел:}

1. Балканов Н. П. Свод законов Российской империи. Полный текст всех 16 томов, согласованный с последними продолжениями, постановлениями, изданными в порядке ст. 87 Зак. Осн., и позднейшими узаконениями: алфавитный указатель к Своду законов Российской империи. Петгроград, 1914. 1030 с.

2. Болградський міський комісаріат поліції. ДАОО (Державний архів Одеської області). Ф. 869. Оп. 1. Спр. 1.

3. Бараннік Р. В. Судові, правоохоронні та правозахисні органи України : навч. посібник. Київ : Дакор, КНТ, 2008. 348 с.

4. Беленков Р. А. Правоохранительные органы : конспект лекций. Москва : Приор-издат, 2003. 112 с.

5. Михайленко П. П. Історія міліції України у документах і матеріалах : в 3 т. Київ : Генеза, 1997. Т. 1 : 1917- 1925. 499 c.

6. Онопенко П. В. Правоохоронні функції української держави: зміст і реалізація : автореф. дис. на здоб. наук. ступеня канд. юрид. наук : 12.00.01, Київ, 2005. 16 с.

7. Гуценко К. Ф. Правоохранительные органы : учеб. для студ. юрид. вузов и ф-тов. Москва : Изд-во Зерцало, 1998. 416 с.

8. Россіхін В. В. Роль та місце пенітенціарних установ в радянській моделі державності України : автореф. дис. ... Д-ра юрид. наук : 12.00.01. В. В. Россіхін; Харк. нац. ун-т внутр. справ. Харків, 2016. 40 с. 